\title{
ÖĞRETMENLERİN DUYGUSAL EMEK DAVRANIŞLARININ İŞDOYUMLARINA ETKİSI
}

\author{
THE EFFECTS OF TEACHERS' EMOTIONAL LABOR BEHAVIORS ON JOB
}

\author{
SATISFACTION
}

\begin{abstract}
Ayhan KARAKAŞ ${ }^{1}$
Rasim TÖSTEN ${ }^{2}$

Veysi KANSU ${ }^{3}$

Ahmet Sedat AYDIN ${ }^{4}$

\section{$\ddot{O} z$}

$\mathrm{Bu}$ araştırmanın temel amacı, öğretmenlerin duygusal emek davranışlarının iş doyumuna etkisini belirlemektir. Araştırma ilişkisel tarama modelindedir. Araştırmanın çalışma grubunu Batman il merkezinde basit tesadüfi örnekleme yoluyla seçilen 380 öğretmen oluşturmaktadır. Öğretmenlerin duygusal emek davranışlarını ölçmek için Begenirbaş ve Meydan (2012) tarafından öğretmenlere uyarlanan Duygusal Emek Davranışları Ölçeği'nden ve Oran (1989) tarafindan Türkçeye uyarlanan Minnesota Doyum Ölçeği'nden yararlanılmıştır. Çalışmada öğretmenlerin duygusal emek davranışları ve iş tatmin düzeyleri için aritmetik ortalamalardan yararlanırken, boyutlar arası ilişkiler ve etkileri korelasyon ve regresyon analizleri ile ortaya konulmuştur. Yapılan analizlerde ulaşılan sonuçlara göre, genel olarak duygusal emeğin işdoyumunu $\% 7$ yordadığı tespit edilmiştir. Özellikle alt boyutlar olarak ele alındığında boyutlar arasında (duygusal emek ile içsel doyum arasında) pozitif ve anlamlı ilişkilere rastlanılmıştır.
\end{abstract}

Anahtar Kelimeler: Duygusal Emek, İşdoyum, Öğretmen

\begin{abstract}
The main aim of this research is to determine the effects of teachers' emotional labor behaviors on job satisfaction. The research is co relational survey model. The study group of the research consisted of 380 teachers in Batman province by simple random sampling. To measure teachers' emotional labor behaviors "Emotional Labor Behavior Scale" which was adapted for teachers by Begenirbaş and Meydan (2012), as well as "Minnesota Satisfaction Scale" which was translated to Turkish by Oran (1989) were used. In the study, while arithmetic mean was used for the teachers' emotional labor behaviors and job satisfaction, relationship among dimensions and their effects were determined by correlation and regression analyzes. According to the findings reached in the analysis, it was found that the overall emotional labor predicted job satisfaction as 7\%. Especially when considered as the subdimensions, there were found positive and significant relationship among the dimensions (between inner satisfaction and emotional labor).
\end{abstract}

Keywords: Emotional Labor, Job Satisfaction, Teacher

\footnotetext{
${ }^{1}$ Yrd.Doç.Dr., Bartın Üniversitesi İİBF İşletme Bölümü, ayhankarakas74@gmail.com

${ }^{2}$ Yrd.Doç.Dr., Siirt Üniversitesi BESYO, rasimtosten@hotmail.com

${ }^{3}$ Batman Milli Eğitim Müdürlüğü, veysikansu@gmail.com

${ }^{4}$ Batman Milli Eğitim Müdürlüğü, sedataydin@gmail.com
} 


\section{Gíriș}

Duygu olgusu, günümüzdeki kadar geniş bir kullanım alanına sahip olmamakla beraber, 1800'lü yılların sonlarından beri üzerinde çalışılan ve çeşitli görüşler ileri sürülen bir alandır. İnsanoğlunun hislerini ve duygusal durumlarını incelemek, bunun çeşitli etkilerini tahmin etmek, literatürde her zaman ilgi çeken bir konuma sahip olması nedeniyle, hissedilenlerin ve duyguların biyolojik, psikolojik, sosyal ve kültürel açılardan çeşitli açıklamalarına rastlamak mümkündür. Özellikle 1980'li yıllardan itibaren, duyguların çalışma yaşamındaki varlığı, dışavurum biçimleri, örgütsel başarıdaki rolü giderek artan bir şekilde tartışılmaya başlanmıştır (Türkay ve Ünal, 2011).

Duygusal emek, işgörenlerin işlerini yaparken müşteride olumlu izlenim uyandırmak için duygularını denetleyerek, önceden belirlenmiş kalıplar halinde müşteriye sunmaları olarak tanımlanmaktadır (Hochschild, 1983:7). Durumun gerektirdiği duyguları uygun bir şekilde ifade etme şeklinde de tanımlanan duygusal emek, özellikle hizmet sektörü için çok önemlidir (Baltaş, 2005:227).

Hizmet sektöründe küresel rekabetin getirdiği toplam kalite anlayışında koşulsuz müşteri memnuniyeti önemli bir rol oynamaktadır (Dollard ve diğg 2003:84). Bunun için birçok işveren, müşterilere karşı nasıl bir tavır sergilenmesi gerektiğini önceden belirleyip gösterilmesi gereken bu duygusal emek davranışlarını kurum içi eğitimlerle işgörenlerden zorunlu olarak istemektedirler. Çalışanların bu davranışları gösterirken içten hissetmesi ya da maskeleme yaparak rol yapması sonucu kendilerinde iş doyumu ya da tükenmişlik oluşabilmektedir (Rafaeli ve Sutton, 1987:26-31; Grandey; 2000:96).

Hizmet sektöründeki hızla büyümeyle duygusal emek olgusu birçok hizmet alanı ve mesleğinvazgeçilmez ve yaygın bir bileşeni olmuştur. Bumesleklerin başında da, sürekli,öğrenci, idareci ve öğrenci velileri ile yüzyüze ilişkiler anlamında görüşmek ve iletişimde bulunmak mecburiyetindeolan öğretmenlerin geldiği düşünülmektedir (Begenirbaş ve Yalçın, 2012).

\section{Duygusal Emek}

Duygusal emek kavramı yazarlar tarafından farklı şekilde tanımlanmıştır. Özkaplan (2009: 19)'a göre duygusal emek, "firmaların müşteriye sattığı paketin bir parçasıdır". Yazara göre, sanayi işçisinin kol gücünü, bilgi teknolojisi işçisinin beyin gücünü sattığı gibi duygu işçisi de "gülümsemelerini" satmaktadır."Duygusal emek, çalışanların müşterilerle yakından ilişkiler kurulmasını gerekli kılan işlerde işin gereklerini sunabilmek için sarf etmek zorunda kaldıkları emek biçimidir ve duyguların dönüştürülmesini içermektedir" (Kalfa ve Topateş, 2009: 425). Duygusal emeği sosyal kimlik kuramı çerçevesinde inceleyen Ashforth ve Humphrey (1993: 90)'e göre duygusal emek, uygun duyguyu sergileme eylemidir.

Morris ve Feldman (1996: 987) duygusal emeği, kişiler arası etkileşim sürecinde kurumun istediği duyguları sergileyebilmek için sarf edilen çaba, planlama ve kontrol olarak tanımlamışlardır. Grandey (1999:8) ise duygu gösterim kurallarına vurgu yaparak duygusal emeği "hem duyguların hem de davranışların kurum amaçlarına hizmet edecek şekilde düzenlenmesi" şeklinde tanımlamıştır.

Çaldağ'a göre (2010), kişiler arası iş süreçlerinde örgütün arzu ettiği duyguları (davranış kuralları) yansıtmada gerekli olan çaba, planlama ve kontroldür. Güngör'e göre (2009), hizmetin sunulması esnasında müşterilerle yaşanan etkileşimde kurum tarafından talep edilen duyguların sergilenmesidir.

Yapılan bu tanımlar 1şığında duygusal emek kavramı, müşteri memnuniyeti sağlamak amacı ile çalışanların müşteriler ile pozitif ilişkiler kurabilmeleri için duygularını kontrol 
etmesi ve kendi duyguları yerine işletmenin gösterilmesini istediği duyguları sergilemesi olarak ifade edilebilir (Kaya ve Serçeoğlu, 2013).

Grandey’e(2000) göre, duygusal emek hizmet veren örgütler içingereklidir çünkü bu örgütlerde çalışanlar, kurallar ve normlar gereği uygunduygusal emek gösteriminde bulunmak zorundadırlar. Bu kapsamda,duygusal emek yardım amaçlı, insanları koruyup kollayan ve hizmet tabanlımesleklerde çalışanlarda (öğretmenler, hemşireler, uçuş ve satış görevlileri)daha sıkça yaşanmaktadır (James, 1989; Pierce, 1995). Aynı şekilde Hochschild (1983) de, yüksek oranda duygusal emek gerektiren işlerdekadın hâkimiyetinden söz ederek, bunlardan bazılarının öğretmenlik,hemşirelik ve satış elemanlığı olduğunu belirtmiştir (Begenirbaş ve Yalçın, 2012:50).

Öğretmenlik sosyal bir beklenti olarak, yetiştirme, fedakârlık veözveriyi gerektiren işlerin en başında gelmektedir (Acker, 1995; Grumet,1988). Ancak karşılığının maddi ve manevi olarak verilmesi konusunda çokfazla düşünülmeyen ve sıradan bir görev olarak algılanmaktadır(Fair weather, 1993). Mc Kinney (1988) ise, kaliteli öğretimin beşbileşeninden bahsederken, öğretmenin en önemli görevlerinden birininöğrencileri eğlendirerek onların ilgisini çekmek olduğunu belirterek,öğretmenlerin ders esnasındaki jest ve mimikleri, değişik anlatım biçimleri,el ve vücut hareketleri ve öğrencilerle kurdukları göz irtibatının öneminedeğinerek, aslında öğretimi bir şova dönüştürme işi olarak belirtmiştir. Buesnada, öğretmenin sergileyeceği ve göstermek zorunda olduğu duygusalemek performansının önemi ortaya çıkmaktadır (Begenirbaş ve Yalçın, 2012).

\section{İşdoyumu}

İşgörenlerin, işte devamlılık sağlaması, performansının yüksek olması ve işini severek yapmaya devam etmesi, işinde istekli olması, kendi işletmesini benimsemesi ve motivasyonun yüksek olması gibi etmenler iş tatminine bağlıdır. İşletmelerin başarısı, işini ve örgütünü benimsemiş işgörenlerin varlığına bağlıdır. Bu tür işgörenlerin varlığı, motivasyon araçlarının uygun bir şekilde kullanılması ile doğru orantılıdır.

İşgörenin işe ve iş ortamındaki ilişkilerine yönelik olarak zaman içinde geliştirdiği bir zihinsel tutum vardır. Zihinsel tutumun oluşmasında çalışanın işi hakkındaki bilgisi, işin sonucuna ilişkin yaklaşımları ve iş ortamının koşulları önemli ölçüde rol oynar. Bu tutumlar olumlu olabileceği gibi olumsuz da olabilir. Bireyin mesleğine olan tutumu olumlu ise işdoyumu, olumsuz ise işdoyumsuzluğu şeklinde nitelendirilebilir (Barutçugil, 2004:388). İ̧̧oyumu ya da doyumsuzluğu, çalışanların işlerine yönelik genel bir tutumunu yansıtmaktadır, bir başka deyişle, çalışanların, işlerine, iş ortamlarına ya da iş arkadaşlarına yönelik duygu, düşünce ve davranışlarının bir ürünü olarak değerlendirilebilir (Solmuş, 2004:186).

İşdoyumubir çalışanın yaptığı işin ve elde ettiklerinin, ihtiyaçlarıyla ve kişisel değer yargılarıyla örtüştüğünü ya da örtüşmesine olanak sağladığını fark etmesi sonucu yaşadığ1 duygu olarak da tanımlanabilir (Barutçugil, 2004:388). İşdoyumu, işten elde edilen maddi çıkarlar ve işgörenin beraber çalışmaktan zevk aldığı iş arkadaşları ile bir eser meydana getirmesinin sağladığı mutluluktur şeklinde de tanımlanmaktadır (Şimşek, Akgemci ve Çelik., 2003:150; Bingöl, 1996:266).

İşgörenlerin, işten tatmin olmalarının veya olmamalarının sebepleri değişiktir. Çeşitli araştırmalarda işdoyumunu etkileyen farklı görüşler ortaya konulmuştur. Örneğin; Kirkcaldy ve Martin (2000:87), hemşireler arasında yapmış oldukları "Hemşireler arasında iş stresi ve doyum" çalışmasında, doyumu etkileyen en önemli etmenler; iş çevresi, güven ve uzmanlık rolü, ev/iş çatışmaları ve organizasyonel yenilikler ile birlikte stresin azaltılması işdoyumuna neden olacağı ve hemşirelerin (hem fiziksel hem de psikolojik) sağlıklı olarak performanslarının artacağı belirtilmiştir. 
Chen'in (2007:116), "Bilgi sistemi personeli arasında işdoyumu" adlı çalışmasında işdoyumunusağlayan etmenler; görevlerin tanımı, profesyonellik, geri bildirim, özerklik ve önemli olmak şeklinde belirlenmiştir. Herzberg, ve diğ., (1968:69) "cinsiyet, eğitim durumu ve yaşın", Smith "eğitim, iş kullanımı, refaha ve çöküşe yönelik şartların", McDonald ve Gundersan "yaş, hizmet süresi ve ücretin pozitif olması", Deci "fazla ücret, değişen iş, otonomi, katılım", Witt ve Mye (1992) "adil olma" işdoyumunuetkileyen etmenler (Türk, 2007:74) olduğunu öne sürmüşlerdir.

Kişinin işinde deneyim kazanması için iş yerinde bir müddet çalışmış olması gerekir. İşe yeni giren kişinin işini tanımadan hemen tatmin veya tatminsizlik duymasını beklemek doğru olmaz. İşdoyumunusağlayan etmenleri kişiye, işletmeye ve çevreye bağlı olarak ayırmak mümkündür (Erdoğan, 1999:234; Türk, 2007:76).

\section{Duygusal Emek ve İşdoyum İlişkisi}

Duygusal emek Hochschild (1983)'ün çalışması ile duyguların ücret karşılığı olarak satılması anlamında kullanılarak alanyazına girmiştir. Duygusal emek hizmet sektörü çalışanları üzerinde daha fazla çalışılmış, yapılan çalışmalar; müşteri hizmetleri temsilcileri (Abraham, 1998; Brotheridge ve Grandey, 2002; Austin ve diğ, 2008), çağn merkezi çalışanları (Rupp ve Spencer, 2006; Goodwin, Groth ve Frenkel; Özkan, 2011), sağlık çalışanları (Mikolajczak, Menil ve Luminet, 2007; Köksel, 2009; Çaldağ, 2010), alışveriş merkezi çalışanları (Bayram, Aytaç ve Dursun, 2012; Diefendorf, Croyle ve Gosserand, 2005; Rafaeli ve Sutton, 1990), eğitim çalışanları (Uysal, 2007; Kaya, 2009), finans çalışanları (Öz, 2007; Pugh, 2001; Diamond, 2005) üzerine yoğunlaşmıştır.

Hizmet işlerinin sunulmasında fiziksel, zihinsel ve duygusal emeği de talep edilen hizmet çalışanlarının, konaklama endüstrisi özelinde hizmet ürününe katma değer kattıkları varsayımı nedeniyle, duygusal emek ve yönetimi önemli bir olgu olarak görülmektedir (Chu ve Murrmann, 2006; Van Dijkvd, 2009).

İşten ayrılma niyeti ve işdoyumupek çok endüstriyel ve örgütsel psikolog, yönetim bilimcisi ve sosyologun ilgi alanlarının merkezinde yer almaktadır (Samad, 2006).

\section{Araştırmanın Amacı}

$\mathrm{Bu}$ araştırmanın temel amacı, öğretmenlerin duygusal emek davranışlarının işdoyumuna etkisini belirlemektir. Bu temel amaç kapsamında aşağıdaki sorulara cevap aranmaktadır:

1. Öğretmenlerin duygusal emek davranışları ve işdoyum düzeyleri nedir?

2. Öğretmenlerin duygusal emek davranışları ve işdoyum arasındaki ilişki nedir?

3. Öğretmenlerin duygusal emek davranışları işdoyumunun yordayıcısı mıdır?

\section{YÖNTEM}

$\mathrm{Bu}$ araştırma nicel bir çalışma olup ilişkisel tarama modelindedir. İlişkisel tarama modelleri, iki ve daha çok sayıdaki değişken arasında birlikte değişim varlığını ve derecesini belirlemeye yarayan bir modeldir (Karasar, 2007).

\section{Evren ve Örneklem}

$\mathrm{Bu}$ çalışma öğretmenler üzerinde yapılmıştır. Araştırmanın evrenini 2014-2015 öğretim y1lında görev yapan 6270 öğretmen oluşturmaktadır. Örneklem grubunu ise Batman ilinde rastgele seçilen 380 öğretmen oluşturmaktadır. Büyüköztürk vd. (2010)'a göre örneklem sayısı evreni temsil edebilecek büyüklükte olup (\%5'lik hata payı için) bu sayı yeterlidir. 
Tablo 1: Araştırmada yer alan katılımcılara ait bilgiler

\begin{tabular}{|c|c|c|c|c|c|c|c|c|c|}
\hline Cinsiyet & f & $\%$ & $\begin{array}{l}\text { Medeni } \\
\text { Durum }\end{array}$ & f & $\%$ & Görevi & f & \multicolumn{2}{|c|}{$\%$} \\
\hline Kadın & 118 & 32,0 & Evli & 235 & 63,7 & Yönetici & 28 & \multicolumn{2}{|c|}{7,6} \\
\hline Erkek & 251 & 68,0 & Bekâr & 134 & 36,3 & Öğretmen & 341 & \multicolumn{2}{|c|}{92,4} \\
\hline Toplam & 369 & 100,0 & Toplam & 369 & 100,0 & Toplam & 369 & \multicolumn{2}{|c|}{100,0} \\
\hline $\begin{array}{l}\text { Mesleki } \\
\text { Kidem }\end{array}$ & f & $\%$ & \multicolumn{2}{|c|}{$\begin{array}{c}\text { Şu anda çalıştığı } \\
\text { okuldaki geçen süre }\end{array}$} & f & $\%$ & Yaş & f & $\%$ \\
\hline $1-5$ & 178 & 48,2 & \multicolumn{2}{|l|}{$1-5$} & 311 & 84,3 & $20-30$ & 184 & 49,9 \\
\hline $6-10$ & 106 & 28,7 & \multicolumn{2}{|c|}{$6-10$} & 40 & 10,8 & $31-40$ & 158 & 42,8 \\
\hline $11-15$ & 53 & 14,4 & \multicolumn{2}{|c|}{$11-15$} & 13 & 3,5 & $41-50$ & 23 & 6,2 \\
\hline $16-20$ & 21 & 5,7 & \multicolumn{2}{|c|}{$16-20$} & 2 &, 5 & $50+$ & 4 & 1,1 \\
\hline 21- üstü & 11 & 3,0 & \multicolumn{2}{|c|}{ 21- üstü } & 3 & , 8 & & & \\
\hline Toplam & 106 & 100 & \multicolumn{2}{|c|}{ Toplam } & 369 & 100,0 & Top. & 369 & 100,0 \\
\hline
\end{tabular}

Araştırmada yer alan katılımcıların \%32'si kadın ve \%68'i erkek; \%63,7'si evli ve \%36,3'ü bekar; \%92,4'ü öğretmen pozisyonunda ve \%7,6's1 ise yönetici pozisyonunda görev yapmaktadır. Ayrıca, katılımcıların mesleki kıdemleri ve yaşlarına bakıldığında \%77'nin (1-10 y1l arası) genç olduğu görülmektedir.

Veri Toplama Araçları

Araştırmada kullanılan veri toplama aracı olarak "duygusal emek davranışları ölçeği”" ile "Minnessota işdoyum ölçeği”" kullanılmıştır. Ölçeklere ait bilgiler aşağıdadır.

Duygusal Emek Davranışları Ölçeği: Duygusal Emek harcama yönündeki davranışları ölçmeye yönelik olarak, Begenirbaş ve Meydan (2012) öğretmenler için uyarlanan Duygusal Emek Davranışları Ölçeği kullanılmıştır. Ölçek araştırma içinde kısaca DEDÖ olarak adlandırılmıştır.

Ölçek, daha önce Ünler Öz (2007) tarafından Türkçeye uyarlanan Duygusal Emek Davranışlarının Çalışanların İş Sonuçlarına Etkisi konulu araştırmada kullanılmış olup sonrasında Begenirbaş ve Meydan (2012) tarafindan eğitim sektörüne adapte edilmişstir. Ölçekte yer alan maddelerden oluşturulan soru formu, özel bir okulda çalışan öğretmen yönetici ve psikolojik danışmanlardan oluşan bir grupta incelenmiş, uygulanmış ve uygun olmayan sorular elenerek ön hazırlık çalışması için uzmanlardan yararlanılmıştır. Ölçek 10 sorudan oluşmaktadır. Ölçeğin güvenirlik çalışması Cronbach's Alpha analizleri ile gerçekleştirilmiş ve 0,83 katsayısı bulunmuştur. Faktör analizine tabi tutulan ölçek iki faktör altında gruplanmıştır. Bu faktörlerin soru numaraları 1,5,7,8 ve 9 numaralı sorular bir faktörü (Duygusal Davranış Kurallarına Uyma Davranışı) oluşturmuş ve kısaltma olarak DDKUD şeklinde belirtilmiştir. Ölçekte 2,3,4,6 ve 10 numaralı sorular ise ikinci faktörü (Duyguların kontrolü davranışı) oluşturmuşlarıdır. Bu alt ölçek ise DKD olarak kısaltılmıştır.

İş Doyumunun Ölçülmesi: Araştırmada veri toplama aracı olarak Minnessota Doyum Ölçeği (Minnessota Satisfaction Questionnaire) formundan yararlanılmıştır. İş doyumunu ölçmek üzere, Weiss, DavisEngland ve Lofquist (1967) tarafından geliştirilen ve Oran (1989) tarafından Türkçeye uyarlanan Minnesota Doyum Ölçeği'nden (Minnesota Satisfaction Questionnaire) yararlanılmıştır. Ölçeğin orijinalinin güvenirlik katsayısı, .83'tür (Moorman, 1993). Türkiye'deki güvenirlik çalışması Yıldırım (1996) tarafından yapılmış, test-tekrar test güvenirlik katsayısı.76, iç tutarlılık katsayısı.90 olarak bulunmuştur. Ölçek 20 maddeden oluşmakta, 5 basamaklı yanıt çizelgesi üzerinden değerlendirilmekte ve puan artıkça iş doyumu da artmaktadır. Minnesota İş Doyum Ölçeği 1-5 arasında puanlanan beşli Likert tipi bir 
ölçektir. Ölçek puanlamasında, Hiç memnun değilim; 1 puan, Memnun değilim; 2 puan, Kararsızım; 3 puan, Memnunum; 4 puan, Çok memnunum; 5 puan olarak değerlendirilmektedir. Ölçekte ters soru bulunmamaktadır. Minnesota İş Doyum Ölçeği içsel, dışsal ve genel doyum düzeyini belirleyici özelliklere sahip 20 maddeden oluşmuştur.

1-İçsel doyum: 1,2,3,4,7,8,9,10,11,15,16,20 numaralı sorulardan oluşan içsel doyum alt testi, başarı, tanınma veya takdir edilme, işin kendisi, işin sorumluluğu, yükselme ve terfi etmeye bağl1 görev değişikliği gibi işin içsel niteliğine ilişkin tatminkârlıkla ilgili öğelerden oluşmaktadır. Bu boyutun maddelerinden elde edilen puanlardan İçsel Doyum puanı elde edilmektedir

2-Dışsal doyum: 5,6,12,13,14,17,18,19 maddelerinden oluşur. İşletme politikası ve yönetimi, denetim şekli, yönetici, çalışma ve astlarla ilişkiler, çalışma koşulları, ücret gibi işin çevresine ait öğelerden oluşmaktadır. Bu boyutun maddelerinden elde edilen puanların toplamından ise dışsal doyum puanı bulunur.

\section{Verilerin Analizi}

Araştırmada yer alan amaç kapsamında öğretmenlerin duygusal emek ve iş tatmin düzeylerini belirlemek amacıyla aritmetik ortalama ve standart sapma puanlarına bakılmıştır. Beşli Likert tipi derecelemede değer aralıkları 1.00-1.80, 1.81-2.60, 2.61-3.40, 3.41-4.20, 4.215.00 olarak belirlenmiştir.

Duygusal emek ve işdoyumuilişki düzeyini, yönünü ve gücünü ortaya koymak için pearson korelasyon testi; duygusal emeğin iş tatmini üzerindeki etkisini ortaya koymak için ise regresyon analizinden yararlanılmıştır.

\section{BULGULAR VE YORUM}

Araştırmanın araştırma soruları doğrultusunda elde edilen bulgulara ait tablolar ve yorumları aşağıda yer almaktadır.

\section{Öğretmenlerin Duygusal Emek Davranışları ve İşdoyum Düzeylerine ait Bulgular ve Yorum}

Tablo 2: Öğretmenlerin Duygusal Emek Davranışları ve İşdoyumlarına İlişkin Betimsel Analiz Sonuçları

\begin{tabular}{lccc} 
& $\mathrm{N}$ & $\mathrm{X}$ & $\mathrm{Ss}$ \\
\hline Duygusalemek & 369 & 3,41 &, 54 \\
\hline DDKUD & 369 & 3,80 &, 60 \\
\hline DKD & 369 & 3,01 &, 68 \\
\hline İşdoyum & 369 & 3,39 &, 62 \\
\hline İçseldoyum & 369 & 3,58 &, 66 \\
\hline Dişsaldoyum & 369 & 3,11 &, 71 \\
\hline
\end{tabular}

Tablo 2'ye bakıldığında öğretmenlerin duygusal emek davranışlarına ait ölçekte yer alan yargılara "sık sık" düzeyinde $(\overline{\mathrm{X}}=3.41)$ katıldıkları görülmektedir. Bu durumda öğretmenlerin çalıştıkları kurumda öğrenci ve velilerle girdikleri etkileşimlerde duygusal emek davranışlarını sıç̧a gösterdikleri düşünülebilir. Duygusal Davranış Kurallarına Uyma Davranışlarını (DDKUD) içeren boyuta bakıldığında öğretmenlerin bu boyutta da duygusal davranış kurallarına sıkça $(\overline{\mathrm{X}}=3.80)$ uydukları; Duyguların kontrolü davranışlarını (DKD) ise "bazen” $(\bar{X}=3.01)$ gösterdikleri söylenebilir. 
Tablo 2'ye bakıldığında öğretmenlerin işdoyum düzeylerinin orta düzeyde olduğu ( $\overline{\mathrm{X}}$ =3.39) görülmüştür. Bir başka ifadeyle öğretmenlerin icra ettikleri mesleklerine ait memnuniyetlerinin orta düzeyde olduğu söylenebilir. Bununla birlikte değer aralığının (2.613.40) üst sınırına yakın olması dikkat çekmektedir. Öğretmenlerin mesleğe yönelik içsel doyumun yüksek olduğu $(\bar{X}=3.58)$, dişsal doyumun ise orta düzeyde $(\bar{X}=3.11)$ olduğu görülmüş̧ür.

\section{Öğretmenlerin Duygusal Emek Davranışları ve İşdoyum Arasındaki İlişkiye Ait Bulgular ve Yorum}

Tablo 3: Öğretmenlerin Duygusal Emek Davranışları ve İşdoyumlarınaait Korelasyon Sonuçları

\begin{tabular}{|c|c|c|c|c|c|c|}
\hline & \multicolumn{6}{|c|}{ Boyutlar arası korelasyon } \\
\hline & DDKUD & DKD & İçseldoyum & Dışsaldoyum & İşdoyum & Duygusalemek \\
\hline DDKUD & 1,000 & & & & & \\
\hline DKD & ,369 & 1,000 & & & & \\
\hline İçseldoyum & ,243 & ,144 & 1,000 & & & \\
\hline Dışsaldoyum & ,158 & 146 & ,661 & 1,000 & & \\
\hline İşdoyum & ,227 & ,158 & ,940 & ,878 & 1,000 & \\
\hline Duygusalemek & ,804 & ,849 & ,230 & ,183 & ,230 & 1,000 \\
\hline $\mathrm{p}<.05$ & & & & & & \\
\hline
\end{tabular}

Öğretmenlerin duygusal emek davranışları ve işdoyumlarına ait korelasyon sonuçlarına bakıldığında $(\mathrm{p}<.05 ; \mathrm{r}=.23)$ duygusal emek davranışları ile işdoyumu arasında pozitif yönde düşük düzeyde bir korelasyonun olduğu görülmektedir. İşdoyum ile duygusal emek davranışları boyutları arasındaki korelasyona bakıldığında içsel doyum ( $\mathrm{r}=.23)$ ve dişsal doyum $(\mathrm{r}=.18)$ düzeyi arasında pozitif yönde düşük düzeyde bir ilişkinin olduğu söylenebilir (Cohen, 1988).

Duygusal emek davranışlarının kendi içindeki boyutlar içikorelasyonuna bakıldığında DDKUD ile DKD arasında pozitif yönde orta düzeyde bir ilişkinin olduğu ( $\mathrm{r}=.37)$; DDKUD ile Duygusal Emek Davranışı arasında ve DKD ile Duygusal Emek Davranışı arasında pozitif yönde ve yüksek düzeyde bir ilişkinin olduğu söylenebilir $(\mathrm{p}<.05)$.

İşdoyum düzeyinin kendi içindeki boyutlar içi korelasyonuna bakıldığında içsel doyum ile dişsal doyum arasında pozitif yönde yüksek düzeyde bir ilişkinin olduğu $(r=.66)$; içsel doyum ile işdoyum arasında ve dışsal doyum ile işdoyum arasında pozitif yönde ve yüksek düzeyde bir ilişkinin olduğu söylenebilir $(\mathrm{p}<.05)$.

\section{Öğretmenlerin Duygusal Emek Davranışları İşdoyumunun Yordayıcılığına Ait Bulgular ve Yorum}

Tablo 4. İşdoyumunun İçsel ve Dışsal DoyumAlt Boyutlarının Yordanmasına İlişkin Çoklu Regresyon Analiz Sonuçları

\begin{tabular}{lcccc}
\hline & $\begin{array}{l}\text { Yordayııı Değişken } \\
\text { Yıldırma (Mobbing) }\end{array}$ & $\begin{array}{c}\beta \\
\text { (Beta ) }\end{array}$ & $\mathrm{t}$ & $\mathrm{p}$ \\
\hline Yordanan Değişken & & .220 & 4.040 & $.00 * *$ \\
$($ İçsel doyum) & DDKUD & .062 & 1.147 & $.05^{*}$ \\
$\mathrm{R}=.25 \mathrm{R}^{2}=.07 \mathrm{~F}_{(2-366)}=12.195$ & DDK & & & \\
\hline
\end{tabular}




\begin{tabular}{|c|c|c|c|c|}
\hline $\begin{array}{l}\text { Yordanan Değişken } \\
\text { (D1şsal doyum) } \\
\mathrm{R}=.19 \mathrm{R}^{2}=.04 \quad \mathrm{~F}(2-366)=6.405\end{array}$ & $\begin{array}{c}\text { DDKUD } \\
\text { DDK }\end{array}$ & $\begin{array}{l}.121 \\
.101\end{array}$ & $\begin{array}{l}2.186 \\
1.836\end{array}$ & $\begin{array}{l}.03 * \\
.07\end{array}$ \\
\hline $\begin{array}{l}\text { Yordanan Değişken } \\
\text { (Toplam İşdoyumu) } \\
\mathrm{R}=.24 \mathrm{R}^{2}=.07 \quad \mathrm{~F}(2-366)=11.272\end{array}$ & $\begin{array}{c}\text { DDKUD } \\
\text { DDK }\end{array}$ & $\begin{array}{l}.196 \\
.086\end{array}$ & $\begin{array}{l}3.582 \\
1.573\end{array}$ & $\begin{array}{c}.00 * * \\
.11\end{array}$ \\
\hline $\begin{array}{l}\text { Yordanan Değişken } \\
\text { (Toplam İşdoyumu) } \\
\mathrm{R}=.24 \mathrm{R}^{2}=.07 \quad \mathrm{~F}(1-367)=20.539\end{array}$ & Duygusal Emek & .230 & 4.532 & $.00 * *$ \\
\hline
\end{tabular}

Tablo 4'te işdoyumunun içsel ve dışsal doyum alt boyutlarının yordanmasına ilişkin çoklu regresyon analiz sonuçları incelendiğinde, duygusal emek davranışlarının DDKUD ve DDK alt boyutlarınıniçsel doyum boyutu üzerinde anlamlı bir etki meydana getirdiği görülmektedir $\left(\mathrm{R}=.25 \quad \mathrm{R}^{2}=.07, p \leq .05\right)$. Duygusal emek davranışlarınıniki alt boyutu birlikte, öğretmenlerin içsel doyum boyutundaki duygusal emek davranışları toplam varyansın \%7'sini açıklamaktadır.

Duygusal emek davranışlarının DDKUDalt boyutunundışsal doyum boyutu üzerinde anlamlı bir etki meydana getirdiği $\left(\mathrm{R}=.19 \mathrm{R}^{2}=.04, p \leq .05\right)$; DDK alt boyutunun ise anlamlı bir etki meydana getirmediği ( $>$ >.05) görülmektedir. Duygusal emek davranışlarının iki alt boyutu birlikte, öğretmenlerin dışsal doyum boyutundaki duygusal emek davranışları toplam varyansın \%4'ünü açıklamaktadır.

Duygusal emek davranışlarının DDKUD alt boyutununişdoyumun tamamı üzerinde anlamlı bir etki meydana getirdiği $\left(\mathrm{R}=.24 \mathrm{R}^{2}=.07, p \leq .05\right)$; DDK alt boyutunun ise anlamlı bir etki meydana getirmediği ( $\mathrm{p}>.05)$ görülmektedir. Duygusal emek davranışlarının iki alt boyutu birlikte, öğretmenlerin dışsal doyum boyutundaki duygusal emek davranışları toplam varyansın \%7'sini açıklamaktadır.

Duygusal emek davranışlarının boyut ayrımı gözetmeksizinişdoyumun tamamı üzerinde anlamlı bir etki meydana getirdiği görülmektedir $\left(\mathrm{R}=.24 \mathrm{R}^{2}=.07, p \leq .05\right)$. Duygusal emek davranışları öğretmenlerin işdoyumu için toplam varyansın \% 7'sini açıklamaktadır.

\section{SONUÇ VE TARTIŞMA}

Duygusal emeğin çalışanların işe bağlılıklarını hangi yönde nasıl etkilediği son zamanların araştırma konularından birisi olmuştur. Yapılan bu araştırmada eğitim örgütlerinde öğretmenlerin öncelikle duygusal emek davranışlarını ne sıklıkta gösterdikleri ortaya konulmuştur. Öğretmenlerin çalıştıkları kurumda öğrenci ve velilerle girdikleri etkileşimlerde duygusal emek davranışlarını "sıkça" gösterdikleri görülmüştür. Duygusal emek davranışları örgütün amaçları doğrultusunda meslek gereği olarak girilen etkileşimde duyguların yönetilmesini, memnuniyeti, açık ve iknacı etkileşimi esas alan bir girişim/çaba olarak görüldüğünde (Kalfa ve Topateş, 2009; Özkaplan, 2009; Ashforth ve Humphrey, 1993; Morris ve Feldman,1996; Grandey, 1999), öğretmenlerin bu çaba karşısındaki beklentilerinin önemi büyük olacaktır.

Yapılan araştırmanın bir diğer konusu ise öğretmenlerin işdoyumlarıdır. Öğretmenlerin icra ettikleri mesleklerine ait işdoyumlarının orta düzeyde olduğu görülmüştür. İşdoyumun çalışan üzerinde olumlu ve olumsuz etkisinden bahsetmek mümkündür. İş doyumunun yüksek olması yönetsel vedavranışsal olumlu sonucu beraberinde getirirken, düşük olması da olumsuz sonuçlara nedenolabilmektedir. Örneğin, çalışanın fiziksel ve ruhsal sağlığının iş doyumu ve örgütün başarısında etkisi büyüktür (Akıncı, 2002; Şahin, Aydoğdu ve Yoldaş, 2011). Araştırmalarda işinden memnun olan çalışanların yaşamlarında da memnun oldukları, çalışma performansının yüksek olduğu, işe geç kalma ve devamsızlık gibi problemlerle daha az 
karşılaştıkları görülmüştür. Bu durum duygusal emekle ve duygusal uyumla da ilgilidir (Başbuğ, Ballı ve Oktuğ, 2010 ).

Araştırmada öğretmenlerin duygusal emek davranışları ile işdoyumu arasındaki ilişki incelenmiştir.Araştırma sonucunda duygusal emek davranışları ile işdoyum düzeyleri arasında pozitif yönde ilişkinin olduğu görülmüştür. Tutar (2007), işgörenlerin işdoyumu buldukları yerde çalışmayı isteyeceğini; çünkü işdoyumuçalışanların emek verimlilikleriyle doğrudan ilgili olduğunu belirtmektedir.

Son olarak öğretmenlerin iş doyumunun yordanmasında duygusal emek davranışlarının kısmi olarak etkili olduğu görülmüştür. Benzer şekilde Liu, Prati, Perrewe ve Ferris (2008) yaptığı bir çalışmada duygusal emeğin işdoyumu üzerinde etkili olduğu görülmüştür. Savaş (2012), duygusal zeka, duygusal emek ve işdoyum arasındaki ilişkiyle ilgili yapmış olduğuçalışmada öğretmenlerin iş doyumunun yordamasında okul müdürlerinin duygusal emeklerinin kısmi aracılık etkisini bulmuştur. Yine duygusal emeğin işdoyumu üzerindeki aracılık etkisinin bulunduğu farklı çalışmalar da mevcuttur (Başbuğ, Ballı ve Oktuğ, 2010; Oral ve Köse, 2011).

Öğretmenler, pozisyon gereği öğrencilerle, velilerle, sair meslektaş gruplarıyla ve toplumun tüm paydaşlarıyla etkileşim içerisindedirler. Eğitimin yalnızca okuldan ibaret olmadığı ve yaşamboyu devam ettiği düşünüldüğünde, öğretmenlerin mesleki misyon gereği bu süreçte rol alması kaçınılmazdır. Meslek memnuniyetinin ve işdoyumunun yüksek olması hem bireysel hem de örgütsel anlamda katkı sağlayacaktır. Bu bakımdan mesleki ve örgütsel amaçların farkında olarakduygularını kontrol edebilen nerede ve ne zaman nasıl davranacaklarını bilenöğretmenlerin yani duygusal emek davranışlarını bilinçli sergileyen bir öğretmenin gerek mesleki hayatta gerekse toplum hayatında daha etkili olması beklenir.

Öğretmenlik mesleği, duygusal emek gerektiren bir meslek olduğu için, eğitim-öğretim odaklı ve özellikle öğretmenlerin etkisinin yoğun olduğu faaliyetlerde, onların duygu durumlarının göz önünde bulundurulmasının, onların daha etkin, özverili ve gönüllülük esasına dayalı olarak ilave görevler üstlenmesinde önem arz ettiği sonucuna ulaşılmıştır. Bu nedenle eğitim kurumlarında öğretmenlerin uyması gereken kurallar ve davranış kalıplarını çok biçimselleştirilmeyen, bir başka anlamda onları sahte ve yapmacık duygu gösterimlerinde bulunmalarına zorlamadan, doğal ve içten gelen duygularını ön plana çıkaracak tarzda daha bir yönetim anlayışının uygulanmasının, öğretmenlerin işdoyumununa imkân sağlayacağ1 söylenebilir. Bu yönetim tarzının demokratik, katılımcı ve istisnalarla yönetim anlayışının yerleştirilerek, öğretmenlerin öz güvenlerinin gelişmesi ve öz yeterliliklerinin ortaya çıkarılması ile mümkün olabileceği düşünülmektedir. Okullarda bu anlayış paralelinde bir çalışma ortamının yaratılmasının öğretmenler için olduğu kadar, öğrenciler, idareciler ve nihayetinde eğitim sisteminin kalitesi ve etkinliğin artmasına katkı sağlayacağ1 düşünülmektedir.

Gelecek çalıșmalar için, çalışmada ele alınan iki değişkenin öncül ve ardılları ile aracılık ve düzenleyicilik etkileri söz konusu olabilecek örgütsel davranış değişkenleri ile farklı araştırma modelleri oluşturulabilir. Ayrıca, duygusal emeğin gerekli olduğu ve işdoyumunun sergilenebileceği değişik örgüt ve meslek dallarında (sağlık, güvenlik, vb.) çalışan katılımcı gruplarla yapılacak benzer çalışmalarla, daha genellenebilir sonuçlara ulaşılabilir. 


\section{KAYNAKÇA}

Abraham, R. (1998). Emotional Dissonance in Organizations: Antecedents, Consequences, and Moderators. Genetic, Socialand General Psychology Monographs. 124(2), 229-246.

Acker, S. (1995). Carry on Caring: The Work of Women Teachers. British Journal of Sociology of Education, 16(1), 21-36.

Akıncı, Z. (2002). Turizm sektöründe işgören iş tatminini etkileyen faktörler: Beş yıldızlı konaklama işletmelerinde bir uygulama. Akdeniz I.I. I.B.F. Dergisi, (4), 1-25.

Ashforth, E. B.,\&Humphrey, H. R. (1993). Emotionallabor in service roles: The influence of identity. Academy of Management Review. 18(1), 88-115.

Austin, Elizabeth J.;Timothy C. P Dore\&Katharine M. O'Donovan (2008). Associations of Personality and Emotional Intelligence with Display Rule Perceptions and Emotional Labour. Personality and Individual Differences, 44(3,) 679-688.

Avcı, U.,\&Boylu, Y. (2010). Türk Turizm Çalışanları İçin Duygusal Emek Ölçeği Geçerlemesi. SOID Seyahat ve Otel Işletmeciliği Dergisi. 7(2)

Baltaş, A.,\&Baltaş, Z. (2000). Stres ve Başaçıkma Yolları. (20. B). İstanbul: Remzi Kitapevi.

Barutçugil, İ. (2004). Organizasyonlarda Duyguların Yönetimi. İstanbul: Kariyer Yayınları.

Barutçugil, İ. (2004). Stratejik İnsan Kaynakları Yönetimi. İstanbul: Kariyer Yayıncılık.

Basım, H. N.,Beğenirbaş, M.,\& Can Yalçın, R.(2013). Effects of Teacher Personalities on Emotional Exhaustion: Mediating Role of Emotional Labor. Educational Sciences Theory and Practice, 13(3), 1488-1496.

Başbuğ, G. , Ballı, E.,\&Oktuğ, Z. (2010). İş doyumu duygusal emek etkisi: Çağrı merkezi çalışanlarının üzerine bir çalışma. Sosyal Siyaset Konferansları Dergisi, (58), 253-274.

Bayram, N., Aytaç, S.,\& Dursun, S. (2012). Emotinal Laborand Burnout at Work: A Study From Turkey. International Congress on Interdisciplinary Business and Social Science, 300-305.

Begenirbaş, M.,\& Yalçın, R. C. (2012). Öğretmenlerin Kişilik Özelliklerinin Duygusal Emek Gösterimlerine Etkileri. Cag University Journal of Social Sciences. 9(1), 47-66.

Beğenirbaş, M.,\& Meydan, C. H. (2013). Duygusal Emeğin Örgütsel Vatandaşlık Davranışına Etkileri: Kamu Sektöründe Bir Araştırma. 21. Ulusal Yönetim ve Organizasyon Kongresi.

Bingöl, D. (1996). Personel Yönetimi. İstanbul: Beta Basım Yayım.

Brotheridge, C. M.,\&Grandey, A. A. (2002). Emotional Laborand Burnout: Comparing Two Perspectives of 'People Work. Journal of Vocational Behavior, 60 (1), 17-39

Büyüköztürk, Ş.,Çakmak, E. K., Akgün, Ö. E., Karadeniz, Ş., \& Demirel, F. (2010). Bilimsel Araştırma Yöntemleri. (7. b) Ankara: Pegem Akademi

Chen, L. H. (2007). Job Satisfaction Among Information System (IS) Personnel. Computers in Human Behavior, 24, 105-118.

Chu, K. Hei-Lin,\&Murrmann, K. S. (2006). Development and validation of the hospitality emotional laborscale. Tourism Management, 27(6), 1181-1191

Cohen, J. (1988). Statistical power analyze is for the behavioral sciences (2. b) Hillsdale, NJ: Lawrence Erlbaum Associates.

Çaldağ, M. A. (2010). Duygusal Emek Davranışlarının Sağlık Çalı̧̧anlarında İş̧ Sonuçlarına Etkisi.Yayınlanmamış Yüksek Lisans Tezi. Konya: Selçuk Üniversitesi Sosyal Bilimler Enstitüsü.

Diamond, L. M. (2005). From the heart or the gut? Sexual-minority women's experiences of desire for sames exand other-sexpartners. Feminism and Psychology, 15, 10-14.

Diefendorff, M. J.,Croyle, M., \&Gosserand, H. R. (2005). The dimensonality and antecedents of emotional labor strategies. Journal of Vacational Behaviour, 66 (2), 339-357.

Dijk P. V., Smith, L. D.G., \& Cooper, B. K. (2011). Are Youfor Real? An Evaluation Of The Relaitonship Between Emotional Labour And Visitor Outcomes. Tourism Management, (32), $39-45$.

Erdoğan, İ. (1999). Örgütsel Davranış. İstanbul: Dönence Basım ve Yayın Hizmetleri.

Fairweather, J. S. (1993). Faculty rewards reconsidered: The natüre of tradeoffs. Change, 25, 44-47.

Goodwin, R. E.,Groth, M., \&Frenkel, S. J. (2011). Relationships Between Emotional Labor, Job Performanceand Turnover. Journal Vocational Behaviour,79, 538-548. 
Grandey, A. A. (1999). The Effects of Emotional Labor: Employee Attitudes, Stress and Performance. Yayınlanmamış Doktora Tezi. Colorado: Colorado State University, USA.

Grandey, A. A. (2000). Emotion regulation in the workplace: A new way to conceptualize emotionallabor. Journal of Occupational HealthPsychology, 5(1), 95-110.

Grumet, M. (1988). Bitter milk: Women and teaching. Amherst: University of Massachusetts Press

Güngör, M. (2009). Duygusal Emek Kavramı: Süreci ve Sonuçları. Kamu-İs, 11(1):167-184.

Herzberg, F. (1968). One More Time: How Do You Motivate Employees? Harvard Business Review, $46,53-62$

Hochschild, R. A. (1983). The managed hearth: Commercialization of human feeling. Berkeley: University of California Pres.

James, N. (1989). Emotional Labour: Skill And Work In The Social Regulation Of Feelings. Sociological Review.

Karasar, N. (2007). Bilimsel araştırma yöntemi. Ankara: Nobel.

Kaya, E. (2009) Özel Okul Öğretmenlerinin Duygusal Emek Davranışını Algılama Biçimleri İle İş Doyumları Ve İşs Stresleri Arasındaki İlişki. Yayımlanmamış Yüksek Lisans Tezi. İstanbul: Maltepe Üniversitesi.

Kaya, U.,\&Serçeoğlu, N. (2013). Duygu İşçilerinde İşe Yabancılaşma Hizmet Sektöründe Bir Araştırma. Çalışma ve Toplum. 311-346.

Kırkclady, B.D.,\&Martin, T. (2000). Job Stress and Satisfaction Among Nurses: Individual Differences. Stres Medicine. 16, 77-89.

Köksel, L. (2009). İş Yaşamında Duygusal Emek ve Ampirik Bir Çalışma. Yayınlanmamış Yüksek Lisans Tezi. Manisa: Celal Bayar Üniversitesi Sosyal Bilimler Enstitüsü.

Liu, Y.,Prati, L.M., Perrewe, P.L.,\&Ferris, G.R. (2008). The relationship between emotional resources and emotional labor: An exploratory study. Journal of Applied Social Psychology, 38(10), 2410-2439.

McKinney, C. W. (1988). Preservice elementary education majors' knowledge of World geography. United States: Oklahoma. http://files.eric.ed.gov/fulltext/ED305313.pdf.

Mikolajczak, M.,Clementine, M,. \&Olivier, L. (2007). Explaining The Protective Effect of Trait Emotional Intelligence Regarding Occupational Stress: Exploration of Emotional Labour Processes. Journal of Research in Personality, 41, 1107-1117.

Morris, J. A.,\&Feldman, D. C. (1996). The Dimensions, Antecedents, And Consequences Of Emotional Labor, Academy of Management Journal, 21, 989-1010.

Oral, L.,\&Köse, S. (2011). Hekimlerin Duygusal Emek Kullanımı ile İş Doyumu Ve Tükenmişlik Düzeyleri Arasındaki İlişkiler Üzerine Bir Araştırma. Süleyman Demirel Üniversitesiİktisadi Ve İdari BilimlerFakültesi Dergisi, 16.

Öz, Ü. E. (2007). Duygusal Emek Davranışlarının Çalışanların İşs Sonuçlarına Etkisi.İstanbul: Beta Basım Yayım Dağıtım A.Ş.

Özgen, I. (2010). Turizm İsletmelerinde Duygusal Emek. Ankara: Detay Yayıncılık.

Özkan, G. (2011). Duygusal Emek Gerektiren Mesleklerde Örgütsel İletişim Doyumunun Duygusal

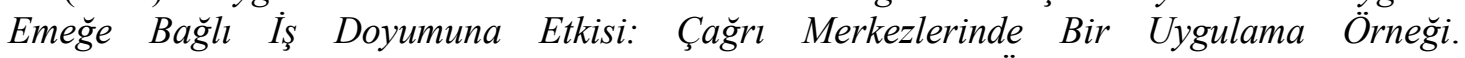
Yayımlanmamış Yüksek Lisans Tezi. Eskişehir: Anadolu Üniversitesi Sosyal Bilimler Enstitüsü.

Özkaplan, N. (2009). Duygusal Emek ve Kadın İşi/Erkek İşi. Çalışma ve Toplum, 2, 15-24.

Pierce, J.L. (1995). GenderTrials: Emotional Lives In Contemporary Law Firms. Berkeley: University of California Press.

Rafaeli, A.,\&Sutton, R. I. (1987). The expression of emotion as part of the work role. Academy of Management Review. 12(1), 23-37.

Rafaeli, A.\&andSutton, R. I. (1990). Busy Stores And Demanding Customers: How Do They Affect The Expression Of Positive Emotion? Academy of Management Journal, 33, 623-637.

Rupp, D. E.,\&Spencer, S. (2006). When customer slash out: The effect of customer interactional injustice on emotional labor and the mediating role of discrete emotions. Journal of Applied Psychology, 91, 971-978.

Samad, S. (2006). Predicting Turnover Intentions: The Case of Malaysian Government Doctors. The Journal of American Academy of Business, Cambridge, 8(2), 113-119. 
Savaş, A. C. (2012). Okul Müdürlerinin Duygusal Zekâ ve Duygusal Emek Yeterliklerinin Öğretmenlerin İş Doyumu Düzeylerine Etkisi.Dumlupınar Üniversitesi Sosyal Bilimler Dergisi, 33

Solmuş T. (2004). İ̧̧ Yaşamında Duygular ve Kişiler Arası İliş̧kiler. Ankara: Beta Yayınları.

Solmuş, T. (2007). Endüstriyel Klinik Psikolojisi ve İnsan Kaynakları Yönetimi. İstanbul: Beta Yayınları.

Şahin, S., Aydoğdu, B., \&Yoldaş, C. (2011).Duygusal Zekâ ve İş Doyumu Arasındaki İlişkiler: Eğitim Müfettişleri Üzerinde Bir Araştırma. İlköğretim Online, 10(3), 974-990

Şimşek, M. S.,Akgemci, T., \&Çelik, A. (2003). Davranış Bilimlerine Giriş ve Örgütlerde Davranış. Konya: Adım Matbaacıllk ve Ofset.

Topateş, H.,\& Kalfa, A. (2009). Yeni Çalışma İlişkileri Bağlamında Örgütsel Yurttaşlık ve Duygusal Emek. Uluslararast Sosyal Haklar Sempozyumu, 22-23.

Tutar, H. (2007). Erzurum'da Devlet Ve Özel Hastanelerde Çalışan Sağlık Personelinin İşlem Adaleti, İş Tatmini Ve Duygusal Bağl1lık Durumlarının İncelenmesi.Süleyman Demirel Üniversitesi İktisadi ve İdari Bilimler Fakültesi Dergisi, 12(3), 97-120.

Türk, M.S. (2007). Örgüt Kültür ve İş Tatmini. Ankara: Gazi Kitabevi.

Türkay, O., Ünal, A., \&Taşar, O. (2011). Motivasyonel ve Yapısal Etkenler Altında Duygusal Emeğin İșe Bağl1lı̆̆a Etkisi. ZKÜ Sosyal Bilimler Dergisi, 7(14), 201-222.

Uysal, A. A. (2007). Öğretmenlerde Gözlenen Duygusal Yaşantı Örüntülerinin ve Duygusal İşçiliğin Mesleki Işs Doyumu ve Tükenmişlik Üzerine Etkisi. Yayınlanmamış Yüksek Lisans Tezi. Muğla: Muğla Üniversitesi.

Van Dijk, P. ve \&Brown, A. K. (2006). Emotional Labour and Negative Job Outcomes: An Evaluation of the Mediating Role of Emotional Dissonance. Journal of Management and Organization. 12(2), 101-115.

Weiss, D.J.,Dawis, R.V., England, G.W.,\&Lofquist, L. H. (1967). Manual for The Minnesota Satisfaction Questionnaire (Minnesota Studies in Vocational Rehabilitation, No. 22), Minneapolis: University of Minnesota.

Witt, L. A.,\&Nye, L. G. (1992). Gender and the relationship between perceived fairness of pay or promotion and job satisfaction. Journal of Applied psychology, 77(6), 910. 